\title{
Sustainable Management of Calcareous Saline-Sodic Soil in Arid Environments: The Leaching Process in the Jordan Valley
}

\author{
Mufeed Batarseh ${ }^{1,2}$ \\ ${ }^{1}$ Chemistry Department, Mu'tah University, P.O. Box 7, Mu'tah 61710, Jordan \\ ${ }^{2}$ Abu Dhabi Polytechnic, P.O. Box 111499, Abu Dhabi, UAE \\ Correspondence should be addressed to Mufeed Batarseh; mufeed.batarseh@adpoly.ac.ae
}

Received 7 October 2016; Revised 10 February 2017; Accepted 16 February 2017; Published 1 March 2017

Academic Editor: Rafael Clemente

Copyright (C) 2017 Mufeed Batarseh. This is an open access article distributed under the Creative Commons Attribution License, which permits unrestricted use, distribution, and reproduction in any medium, provided the original work is properly cited.

\begin{abstract}
A leaching experiment of calcareous saline-sodic soil was conducted in Jordan Valley and aimed to reduce the soil salinity $\leq$ $4.0 \mathrm{dS} \mathrm{m}^{-1}$. The quantification of salt removal from the effective root zone was done using three treatment scenarios. Treatment A contained soil amended with gypsum leaching with fresh water $\left(\mathrm{EC}=1.1 \mathrm{dS} \mathrm{m}^{-1}\right)$. Treatments $\mathrm{B}$ and $\mathrm{C}$ contained nonamended soil, but B was leached with fresh water only while treatment C's soil was washed with saline agricultural drainage water $(\mathrm{EC}=$ $8 \mathrm{dS} \mathrm{m}^{-1}$ ) at the start of the experiment and continued with fresh water to reach the desired soil salinity. All treatments were able to reduce the soil salinity to the desired level at the end of the experiment; however, there were clear differences in the salt removal efficiencies among the treatments which were attributed to the presence of direct source of calcium ion. The soil amended with gypsum caused a substantial decline in soil salinity and drainage water's electrical conductivity and drained the water twice as fast as the nonamended soil. It was found that utilizing agricultural drainage water and gypsum as a soil amendment for calcareous saline-sodic soil reclamation can beneficially contribute to sustainable agricultural management in the Jordan Valley.
\end{abstract}

\section{Introduction}

Saline-sodic soil can significantly reduce the productivity of affected agricultural land. Saline soil has an electrical conductivity (EC) of the saturation soil extract of more than $4 \mathrm{dS} \mathrm{m}^{-1}$ at $25^{\circ} \mathrm{C}[1,2]$. Soil salinity is a major problem facing sustainable development in the agricultural sector in the Jordan Valley and adversely affects soil productivity. Many arid and semiarid regions in the world contain soil and water resources that have high salinity rates not suitable for most common economic crops [3]. Jordan, with an area of $89,556 \mathrm{~km}^{2}$ of which more than $80 \%$ is desert, has more than 180,000 ha of arable land affected by soil salinity [4]. The main sources of soil salinity are either natural (due to parent soil materials, salt deposits, and climatic conditions) or caused by long-term use of fertilizers, low rainfall, and the use of highsalt irrigation water. In the Jordan Valley, these sources are predominantly found on a large portion of land surrounding the Dead Sea area and are naturally high in saline due to the declination of the Dead Sea's water level. In other areas in the Middle and Northern parts of the valley, soil salinity is due to upward movement irrigation practices in hot, dry climatic conditions where dissolved salts accumulate in the root zone $[5,6]$. Removing salts from the root zone can be done by using various methods. Soil leaching is well known to be the most effective procedure, but this requires a large amount of water. Therefore, it is not recommended for a country, such as Jordan, with scarce water resources. Biological methods, such as salt tolerant plants (halophytes) and certain bacterial strains, were reported to be effective in removing salts from the root zone $[2,7]$. Poor irrigation water quality along with saline-sodic soil has reduced plant yield and represents a serious threat to soil productivity. Nevertheless, information on the effects of these methods on soil reclamation is scarce in this region.

Reuse of saline water and amelioration of salt-affected soil is becoming an increasingly vital tool to improve crop production and has created extra farm land which has saved fresh water resources. Additionally, many areas of the world have soil with problems of high salinity and water logging. A large number of subsurface/surface drainage systems have been installed to lower the water table and leach salts from 
saline-sodic soil. Poor quality water can be used for the leaching of saline-sodic soil in areas where there are limited fresh water resources and salt-affected soils.

Sodic soil contains an excess of exchangeable $\mathrm{Na}^{+}$on soil colloids and has soluble carbonates which results in higher soil $\mathrm{pH}$. The amendments to saline-sodic soil are materials that will furnish divalent cations such as $\mathrm{Ca}^{+2}$ to replace exchangeable $\mathrm{Na}^{+}$. The exchange of $\mathrm{Ca}^{+2}$ with $\mathrm{Na}^{+}$in soil results in flocculation of soil particles, the restoration of porous structures, and the increase in soil permeability. The reclamation of sodic soil also requires water high in electrolytes to pass through the soil profile having leaving divalent ions, usually $\mathrm{Ca}^{+2}$, in the soil and washing exchanged $\mathrm{Na}^{+}$ions away from the root zone (Hanay et al. 2004) [8].

Saline-sodic soil containing calcium carbonate $\left(\mathrm{CaCO}_{3}\right)$ is common in arid and semiarid regions (Oster et al. 1996). Since the $\mathrm{CaCO}_{3}$ dissolution rate is too slow to supply enough $\mathrm{Ca}^{+2}$ for ion exchange, an acid or acid former, such as gypsum (Wong et al. 2009), sulfuric acid (Sadiq et al. 2007), or organic matter (Li and Keren 2009), can be applied as a soil amendment to enhance $\mathrm{CaCO}_{3}$ dissolution. Gypsum is the most prevalent agricultural soil amendment used for reclamation of sodic soil. It decreases the damaging effects of high sodium content in irrigation water because of its high solubility, ease of use, and low cost [8]. Several studies have shown that a high application of gypsum to reclaim saline-sodic soils increases the removal of excess $\mathrm{Na}^{+}$from soil and causes a significant reduction in electrical conductivity and sodium adsorption ratio within the soil (Keren 1996; Sadiq et al. 2003; Hamza and Anderson et al. 2003; Hanay et al. 2004). Therefore, the objective of this study was to reclaim saline-sodic soils using gypsum-amended soil, fresh water, and drained water. The study's aim was to facilitate saline soil leaching in an arid environment, such as the Jordan Valley, and to decrease the electrical conductivity of soil salinity to less than $4.0 \mathrm{dS} \mathrm{m}^{-1}$. Additionally, investigations were performed to analyze the leachability of major cations and anions in the soil profile. Finally, the study's other purpose was to ascertain sustainable water management (SWM) practices through preservation of fresh water by leaching saline soil using drained water.

\section{Materials and Methods}

2.1. Field Site and Experiment Preparations. This research was conducted in Ghor Al-Safi, an area in the southern part of the Jordan Valley approximately $20 \mathrm{~km}$ from the southern edge of the Dead Sea. The area is nearly flat with just a slight slope to the west. The climate is subtropical and is characterized by a hot, dry summer season (April to October) and a warm winter season (November to March). Rainfall is less than $80 \mathrm{~mm}$ /year occurring mainly in two or three main events during the winter season $[9,10]$. The soil is characterized by low fertility, organic matter (1.01 to $4.71 \%)$, and CEC $\left(49 \mathrm{cmol} \mathrm{kg}^{-1}\right)[11,12]$. The natural vegetation in this area consists of scattered wild plants tolerant to high salinity, such as Prosopis farcta, Proposi juliflord, and Ziziphus spinachristi [13]. The dominant soil texture is silt with poor soil structure, and the average salinity is $98.1 \mathrm{dS} / \mathrm{m}$ based on a saturated paste test. This land has been categorized as an extremely salty area [14]. A marly layer, $40 \mathrm{~cm}$ thick, was found at approximately $60 \mathrm{~cm}$ deep.

Soil reclamation experiments were conducted using three types of reclamation treatments. The chemical and physical soil properties were measured before and after the reclamation experiments to assess the efficiency of salt removal and to quantify amount of salt removed from the plant effective root zone using different treatments. The treatments were applied, namely, soil amended with gypsum (treatment A), untreated soil consistent with the area (treatment B), and untreated soil (treatment $\mathrm{C}$ ). Treatment $\mathrm{C}$ was washed with agricultural drainage saline water $\left(\mathrm{EC}=8.0 \mathrm{dS} \mathrm{m}^{-1}, \mathrm{Na}^{+}=\right.$ $2743.3 \mathrm{mg} / \mathrm{L}, \mathrm{Ca}^{+2}=1802.7 \mathrm{mg} / \mathrm{L}$, and $\mathrm{Mg}^{+2}=1051.2 \mathrm{mg} / \mathrm{L}$ ) at the start of the experiment, and then leaching continued with fresh water $\left(\mathrm{EC}=1.1 \mathrm{dS} \mathrm{m}^{-1}, \mathrm{Na}^{+}=73.3 \mathrm{mg} / \mathrm{L}, \mathrm{Ca}^{+2}\right.$ $=34.3 \mathrm{mg} / \mathrm{L}$, and $\mathrm{Mg}^{+2}=41.6 \mathrm{mg} / \mathrm{L}$ ) similar to the other treatments. The treatment block consisted of three separate experimental units, each $50 \mathrm{~m}^{2}(5 \mathrm{~m} \times 10 \mathrm{~m})$ and confined by a trench $180 \mathrm{~cm}$ deep to collect drainage water, Figure 1. There were nine experimental units ( 3 treatments $\times$ three replicates). A continuous flooding method was used for soil leaching.

Gypsum was applied to treatment A at an application rate of $10.9 \mathrm{tha}^{-1}$. The gypsum requirement is the amount of applied gypsum (application rate) required to reduce the exchangeable sodium percent (ESP) to $10 \%$ at the end of the experiment, given that the ESP was approximately $42 \%$ according to similar records for the study area [14]. The upper $30 \mathrm{~cm}$ of soil was well mixed and irrigated with fresh water once per week. Treatment B represented soil typically found in the study area. This treatment was continuously washed with fresh water during the experimental period. Conversely, treatment $\mathrm{C}$ was leached initially using saline water until the drainage water reached a salinity value of $20 \mathrm{dS} \mathrm{m}^{-1}$. Afterwards, it was leached with fresh water until the drainage water reached an $\mathrm{EC}$ value of $4 \mathrm{dS} \mathrm{m}^{-1}$.

2.2. Soil, Water Samplings, and Analysis. Soil samples were collected from three depths $(0-50,50-100$, and $100-150 \mathrm{~cm})$ for each treatment at the beginning and after at least 25 weeks of leaching treatments; the data is shown in Tables 1 and 2. From each treatment, 10 samples were taken from 3 depths $(0-50,50-100$, and $100-150 \mathrm{~cm})$ using a soil auger and then homogenized to represent each treatment, in total 30 samples. In summary, three homogenized samples were analyzed for each treatment. The leaching end point was decided when the drainage water's electrical conductivity (EC) reached a value $\leq 4 \mathrm{dS} \mathrm{m}^{-1}$. The chemical and physical properties of the soil samples were measured first in the Chemistry Department and later in the Faculty of Agricultural Laboratories at Mu'tah University, Jordan. The soil soluble ions $\left(\mathrm{Cl}^{-}, \mathrm{SO}_{4}{ }^{-2}, \mathrm{HCO}_{3}{ }^{-}, \mathrm{Na}^{+}, \mathrm{K}^{+}, \mathrm{Ca}^{+2}\right.$, and $\left.\mathrm{Mg}^{+2}\right)$ were determined in the saturated soil paste according to US Salinity Laboratory Staff [15] and Rhoades [16]. The $\mathrm{Cl}^{-}$and $\mathrm{SO}_{4}{ }^{-2}$ ions were analyzed using gravimetric titration and turbidimetric method, respectively. $\mathrm{Ca}^{+2}$ and $\mathrm{Mg}^{+2}$ cations were 

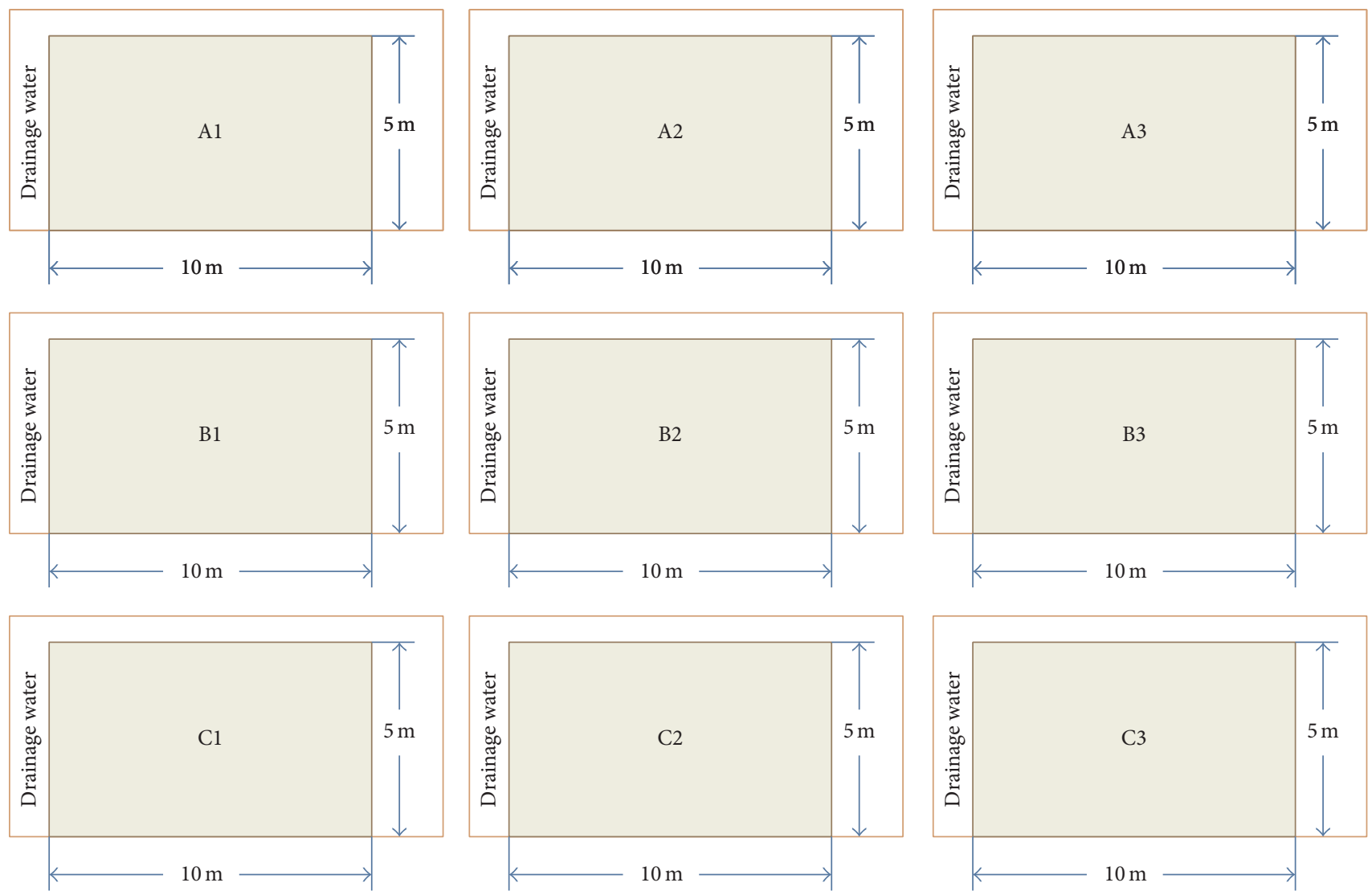

FIGURE 1: Layout of the experimental fields: treatment A (A1-A3), treatment B (B1-B3), and treatment C (C1-C3).

determined by atomic absorption spectrophotometry (AAS). Finally, $\mathrm{Na}^{+}$and $\mathrm{K}^{+}$were analyzed using flame emission photometry (FEP).

While exchangeable $\mathrm{Na}^{+}$and $\mathrm{K}^{+}$were extracted in ammonium acetate and $\mathrm{Ca}^{+2}$ and $\mathrm{Mg}^{+2}$ in sodium acetate according to Rowell [17], they were then analyzed using the same FEP and AAS techniques mentioned above, respectively. Furthermore, EC was measured in the saturated soil paste extract using an EC-meter [16]. Soil texture was determined using the hydrometer method according to Gee and Bauder [18]. OM was determined using the wet oxidation method according to Sparks et al. [19]. CEC was determined by displacement of cations from soil samples with $1 \mathrm{~N}$ ammonium acetate, and determination was done using Flame Photometer (Palemio and Rhoades 1977). Gypsum was analyzed in soil according to the standardized procedure described by Schlichting et al. [20]. The carbonate $\left(\mathrm{HCO}_{3}\right)$ content was determined using a volumetric titration method of soil paste extract (Rhoades et al. 1992).

Water samples were collected from fresh water used for irrigation and soil leaching and drainage water using polyethylene bottles. The water was collected through drainage canals around each treatment at a depth of $1.8 \mathrm{~m}$ during the leaching experiment until its EC value reached $\leq 4 \mathrm{dS} \mathrm{m}^{-1}$. All of the drainage water was pumped out and its quantity measured. Furthermore, it was analyzed for EC and major ionic composition. The following ions $\left(\mathrm{Na}^{+}, \mathrm{Ca}^{+2}\right.$, $\mathrm{Mg}^{+2}, \mathrm{Cl}^{-}$, and $\mathrm{SO}_{4}{ }^{-2}$ ) were analyzed using Dionex Ion Chromatograph Model DX 100 (Dionex, USA).

2.3. Statistical Analysis. Design analysis of variance (ANOVA) was used to test the treatments effected by applying the following mathematical model [21]: $y_{i j}=\mu+$ $\tau_{i}+\beta_{j}+\varepsilon i j$ (where $y_{i j}$ represents the observation from $i j$ th experimental unit (=plot), $\tau_{i}$ represents the effect of treatment $i$, such that the average of each treatment $\bar{T}=\mu+\tau_{i}$, $\varepsilon i j$ are the residuals, the deviations of each observation from their expected values, $\beta_{j}$ is the effect of $j$ th replication, and $\mu$ is the overall mean). Fisher's least significant differences (LSD) were used as a method for comparing treatment means. The statistical analysis was done using Statistical Analysis System (SAS) software.

\section{Results and Discussion}

3.1. Physical and Chemical Soil Properties. The predominant soil texture in the experimental site was silty as recorded in Table 1. High silt content has an adverse impact on soil moisture movement due to its low hydraulic conductivity. The OM content varied from 0.7 to $3.0 \%$ and EC from 27 to $144 \mathrm{dS} \mathrm{m}^{-1}$ for the investigated soil, Table 1 . Thus, the 
TABLE 1: Chemical properties of the soil before starting the leaching experiment (minimum, maximum, average, and standard error).

\begin{tabular}{|c|c|c|c|c|c|c|c|c|c|c|c|c|}
\hline \multirow{2}{*}{$\begin{array}{l}\text { Soil depth }(\mathrm{cm}) \\
\text { Parameter }\end{array}$} & \multicolumn{4}{|c|}{$0-50 \mathrm{~cm}$} & \multicolumn{4}{|c|}{$50-100 \mathrm{~cm}$} & \multicolumn{4}{|c|}{$100-150 \mathrm{~cm}$} \\
\hline & Min & $\operatorname{Max}$ & Average* & Std $^{* *}$ error & Min & $\operatorname{Max}$ & Average & Std error & Min & $\operatorname{Max}$ & Average & Std error \\
\hline$\overline{\mathrm{EC}}(\mathrm{dS} / \mathrm{m})$ & 68 & 144 & 111 & 22.0 & 27 & 81 & 50.6 & 15.6 & 29 & 56 & 44 & 7.8 \\
\hline $\mathrm{pH}$ (unit) & 6.9 & 8.2 & 7.3 & 0.4 & 7.1 & 8.2 & 7.6 & 0.3 & 7.2 & 8.3 & 7.6 & 0.3 \\
\hline $\mathrm{Cl}(\mathrm{meq} / \mathrm{L})$ & 614 & 1377 & 1098 & 222.9 & 230 & 595 & 403 & 105.4 & 319 & 542 & 408 & 64.8 \\
\hline $\mathrm{SO}_{4}(\mathrm{meq} / \mathrm{L})$ & 29 & 307 & 76 & 85.9 & 21 & 60 & 40 & 11.3 & 19 & 72 & 33.5 & 15.8 \\
\hline $\mathrm{HCO}_{3}(\mathrm{meq} / \mathrm{L})$ & 2.4 & 5.2 & 3.1 & 0.8 & 1.6 & 4.2 & 2.4 & 0.8 & 1.8 & 5 & 2.4 & 1.0 \\
\hline $\mathrm{Na}(\mathrm{meq} / \mathrm{L})$ & 330 & 670 & 480 & 98.4 & 144 & 320 & 240 & 50.9 & 108 & 253 & 209 & 42.9 \\
\hline $\mathrm{K}(\mathrm{meq} / \mathrm{L})$ & 17 & 42 & 32 & 7.3 & 10 & 20 & 13 & 3.0 & 8 & 1314 & 11 & 1.6 \\
\hline $\mathrm{Ca}(\mathrm{meq} / \mathrm{L})$ & 125 & 240 & 175 & 33.3 & 39 & 116 & 74.5 & 22.3 & 55 & 88 & 67 & 9.7 \\
\hline $\mathrm{Mg}(\mathrm{meq} / \mathrm{L})$ & 208 & 476 & 333 & 77.4 & 82 & 277 & 144 & 57.5 & 68 & 210 & 141.6 & 41.0 \\
\hline $\mathrm{CaCO}_{3}(\%)$ & 37 & 47.6 & 40 & 3.2 & 35 & 46 & 40.7 & 3.2 & 35 & 45 & 38.6 & 2.9 \\
\hline CEC (meq/100 g) & 14.6 & 18.8 & 17.5 & 1.2 & 10 & 15.7 & 13.1 & 1.6 & 10 & 14.7 & 11.3 & 1.4 \\
\hline Exch. Na (meq/100 g) & 6.8 & 8.2 & 7.5 & 0.4 & 2. & 6.4 & 4.1 & 1.3 & 2.6 & 5.6 & 3.8 & 0.9 \\
\hline Exch. K (meq/100 g) & 2.8 & 3.8 & 3.0 & 0.3 & 2.5 & 3.0 & 2.7 & 0.1 & 1.2 & 3 & 1.8 & 0.5 \\
\hline Exch. $\mathrm{Ca}+\mathrm{Mg}(\mathrm{meq} / 100 \mathrm{~g})$ & 5.0 & 6.8 & 6.7 & 0.6 & 5.5 & 6.3 & 6.3 & 0.3 & 6.0 & 6.1 & 5.7 & 0.1 \\
\hline ESP (\%) & 39 & 97 & 42.9 & 17.1 & 17 & 45 & 31 & 8.1 & 27 & 55 & 33 & 8.6 \\
\hline Organic matter $(\%)$ & 1.1 & 2.4 & 1.8 & 0.4 & 1.0 & 3.0 & 1.8 & 0.6 & 0.7 & 2.1 & 1.1 & 0.4 \\
\hline Gypsum conc. (\%) & 1.5 & 6.2 & 4.1 & 1.4 & 1.8 & 4.5 & 2.8 & 0.8 & 1.7 & 5.0 & 3.3 & 1.0 \\
\hline Saturation percentage (\%) & 57 & 76 & 62 & 5.7 & 63 & 79 & 72 & 4.6 & 58 & 80 & 68 & 6.4 \\
\hline
\end{tabular}

${ }^{*}$ Number of samples: 10 samples were taken from each depth $(0-50,50-100$, and 100-150 cm) and homogenized to represent each treatment in each replicate, in total 30 samples.

${ }^{* *}$ Std error: standard error.

TABLE 2: Exchangeable cation concentrations (meq/100 g soil), electrical conductivity $(\mathrm{dS} / \mathrm{cm})$, and $\mathrm{pH}$ of saturated soil paste extract after the leaching experiment.

\begin{tabular}{|c|c|c|c|c|c|}
\hline \multirow{2}{*}{ Treatment } & \multicolumn{3}{|c|}{ Exchangeable cations (meq/100 g) } & \multirow{2}{*}{$\mathrm{EC} \pm$ Std error } & \multirow{2}{*}{$\mathrm{pH} \pm$ Std error } \\
\hline & $\mathrm{K} \pm$ Std error ${ }^{* *}$ & $\mathrm{Na} \pm$ Std error & $\mathrm{Ca} \& \mathrm{Mg} \pm$ Std error & & \\
\hline & \multicolumn{5}{|c|}{ Soil depth $(0-50 \mathrm{~cm})$} \\
\hline A & $1.68^{\mathrm{a} *} \pm 0.15$ & $0.873^{\mathrm{a}} \pm 0.02$ & $14.96^{\mathrm{a}} \pm 0.15$ & $0.94^{\mathrm{a}} \pm 0.08$ & $7.8^{\mathrm{a}} \pm 0.07$ \\
\hline $\mathrm{B}$ & $1.65^{\mathrm{a}} \pm 0.03$ & $0.983^{a} \pm 0.03$ & $14.86^{\mathrm{a}} \pm 0.01$ & $1.05^{\mathrm{a}} \pm 0.04$ & $7.71^{\mathrm{a}} \pm 0.07$ \\
\hline \multirow[t]{2}{*}{$\mathrm{C}$} & $1.747^{\mathrm{a}} \pm 0.36$ & $1.59^{\mathrm{a}} \pm 0.46$ & $14.16^{\mathrm{a}} \pm 0.80$ & $1.18^{\mathrm{a}} \pm 0.04$ & $7.83^{\mathrm{a}} \pm 0.02$ \\
\hline & \multicolumn{5}{|c|}{ Soil depth $(50-100 \mathrm{~cm})$} \\
\hline A & $2.37^{\mathrm{a}} \pm 0.08$ & $1.48^{\mathrm{a}} \pm 0.10$ & $13.64^{\mathrm{a}} \pm 0.18$ & $1.76^{\mathrm{a}} \pm 0.59$ & $7.7^{\mathrm{a}} \pm 0.13$ \\
\hline B & $2.46^{\mathrm{a}} \pm 0.02$ & $1.79^{\mathrm{a}} \pm 0.17$ & $13.48^{\mathrm{a}} \pm 0.12$ & $1.36^{\mathrm{a}} \pm 0.33$ & $7.81^{\mathrm{a}} \pm 0.08$ \\
\hline \multirow[t]{2}{*}{$\mathrm{C}$} & $2.06^{\mathrm{a}} \pm 0.28$ & $2.02^{\mathrm{a}} \pm 0.41$ & $13.41^{\mathrm{a}} \pm 0.68$ & $1.82^{\mathrm{a}} \pm 0.20$ & $7.94^{\mathrm{a}} \pm 0.01$ \\
\hline & \multicolumn{5}{|c|}{ Soil depth $(100-150 \mathrm{~cm})$} \\
\hline A & $2.44^{\mathrm{a}} \pm 0.07$ & $1.65^{\mathrm{c}} \pm 0.05$ & $13.4^{\mathrm{a}} \pm 0.11$ & $3.2^{\mathrm{a}} \pm 0.24$ & $7.64^{\mathrm{b}} \pm 0.02$ \\
\hline B & $2.52^{\mathrm{a}} \pm 0.03$ & $2.38^{\mathrm{b}} \pm 0.13$ & $12.59^{\mathrm{b}} \pm 0.15$ & $2.01^{\mathrm{b}} \pm 0.26$ & $7.92^{\mathrm{a}} \pm 0.03$ \\
\hline $\mathrm{C}$ & $2.51^{\mathrm{a}} \pm 0.10$ & $2.64^{\mathrm{a}} \pm 0.07$ & $12.33^{\mathrm{c}} \pm 0.11$ & $2.2^{\mathrm{b}} \pm 0.12$ & $7.93^{\mathrm{a}} \pm 0.02$ \\
\hline
\end{tabular}

${ }^{*}$ Superscript letters a, b, and c: statistical analysis significance at $95 \%$ confidence limit. Treatments followed by the same superscript letters were not significantly different at $P<0.05$.

${ }^{* *}$ Std error: standard error.

soil was classified as saline-sodic soil [22]. High soil salinity is a limiting factor for microbial soil activity; it is responsible for OM degradation; hence it accumulates under a saline environment. Moreover, the upper soil depth $(0-50 \mathrm{~cm})$ showed elevated ESP range (39-97\%) because of evapotranspiration as a result of high temperatures in the Jordan Valley. As a result of capillary phenomenon, more salt accumulated in the upper soil horizon [23]. While ESP ranged from 17 to $45 \%$ for the middle soil depth $(50-100 \mathrm{~cm})$, the deepest soil layers $(100-150 \mathrm{~cm})$ showed a high ESP range of $27-55 \%$ because they were in contact with the water table. Therefore, there were big variations in ESP values due to salt accumulation 
before the start of the leaching treatment; this is a normal heterogeneity of saline sodic soil matrix in such an arid environment.

Furthermore, the high concentration of cations and anions, particularly $\mathrm{Na}^{+}$and $\mathrm{Cl}^{-}$, in the soil leads to high soil salinity. The $\mathrm{Cl}^{-}$concentration ranged from 230 to $1377 \mathrm{meq} /$ $\mathrm{L}$ within the surface and deep soil layers. The $\mathrm{Na}^{+}$showed a similar trend to $\mathrm{Cl}^{-}$where its concentration ranged from $108 \mathrm{meq} / \mathrm{L}$ within the deep layers of the soil to $670 \mathrm{meq} / \mathrm{L}$ at the surface layer. The $\mathrm{pH}$ value ranged from 6.9 to 8.3 . The alkaline $\mathrm{pH}$ was due to the presence of high $\mathrm{CaCO}_{3}$ concentrations in the soil [24]. The soil $\mathrm{CaCO}_{3}$ ranged from $35.0 \%$ up to $47.6 \%$. Under alkaline soil, the dissolution of $\mathrm{CaCO}_{3}$ is unlikely, resulting in low $\mathrm{HCO}_{3}$ concentrations (2.4 to $5.0 \mathrm{meq} / \mathrm{L}$ ) as in Table 1; therefore alkaline $\mathrm{pH}$ inhabits the $\mathrm{Ca}^{+2}$ solubility [25]. Thus, the major source of $\mathrm{Ca}^{+2}$ in the soil was gypsum, where gypsum concentration ranged from 1.5 to $6.2 \%$. Gypsum was being utilized for reclamation of sodic soils as a source of $\mathrm{Ca}^{+2}$ to replace $\mathrm{Na}^{+}$(Bresler 1982). Therefore, an extra amount of gypsum was added to the soil since its original amount was not adequate to reclaim saline-sodic soil (Frenkel et al. 1989; Baumhardt et al. 1992). The cumulative water quantities were recorded during the leaching experiments which lasted for at least 25 weeks to reduce the soil salinity to $4.0 \mathrm{dS} \mathrm{m}^{-1}$. These water quantities were 107,101 , and $102 \mathrm{~m}^{3}$ per $50 \mathrm{~m}^{2}$ for gypsum, fresh water, and saline water treatments, respectively (Figure 2). The estimated leached water amounts required for reclamation of the investigated saline-sodic soil were 21400, 20200, and $20400 \mathrm{~m}^{3}$ per hectare, for gypsum, fresh water, and saline water treatments, respectively. These water amounts were considered high for Jordan which suffers from severe water shortage $[12,26]$. Therefore, utilizing agricultural drainage water for leaching processes until reaching $20 \mathrm{dS} \mathrm{m}^{-1}$ of drained water can save around $66 \%\left(13200 \mathrm{~m}^{3}\right.$ per hectare $)$ of fresh water requirements [27]. One drawback of this approach is that using brackish water consumes a larger amount of water compared to the amount needed for leaching with fresh water [28, 29]. Additionally, soil swelling might take place too which may lead to an increase in volume as the soil gets wet and shrinks as it dries out. This phenomenon might occur when a high salt content such as ESP $>15 \%$ in the soil is high [30], and an extensive degradation in soil structure might occur when irrigation waters have SAR $>13$ [31]. A mass balance of $\mathrm{Na}^{+}$shows that not all of the exchangeable sodium can be removed during the reclamation stage, even though excess amounts of gypsum were applied [31].

3.2. Soil Leaching Experiment. Desalinization curves (Figure 3) showed that the three different leaching treatments were able to reduce soil salinity to less than $4 \mathrm{dS} \mathrm{m}^{-1}$ at the end of the experiment. A sharp decline in soil salinity during the first few weeks of the leaching experiment was observed. Then a gradual decrease was observed with successive leaching until the end of the experiment. The gypsum treatment A was the fastest and most effective treatment as the EC declined to less than $20 \mathrm{dS} \mathrm{m}^{-1}$ only in 7 weeks, while treatment $B$ needed 14 weeks and treatment $C$ needed

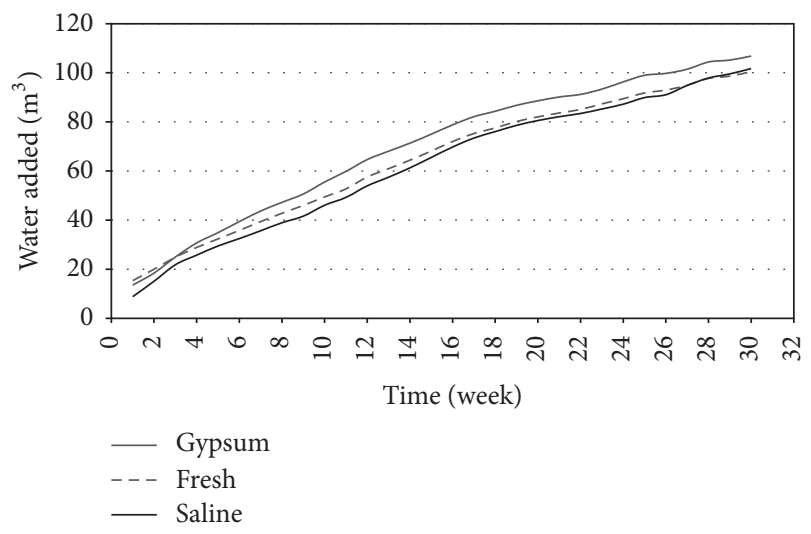

FIGURE 2: Cumulative water quantities $\left(\mathrm{m}^{3}\right)$ added during the leaching process (gypsum amended soil, fresh water, and saline water).

16 weeks, Figure 3. Similar behavior of soil salinity was also reported by Gharaibeh et al. [29]. Gharaibeh et al.s research showed that leached salts were greater at the start of the experiment, but their efficiencies decreased consistently over time. The water quality used for leaching played an important role in the amount of water and time required for salt to be leached from treated soil. The lower the amount of salt in the leaching water, the greater the amount of salt removed. In this study, the phenomenon was also observed in fresh water as the time and amount of leached water were much lower than the saline water. By using different leaching water qualities, there was a difference in the salt removal rate between the three treatments. For example, treatment A showed a sharp decrease in salinity due to the use of gypsum as a rich source of calcium ion: the drop in EC was relatively fast when compared to the other treatments, as shown in Figure 3. This behavior relates to the flocculation of soil particles which is a distinctive occurrence when gypsum is applied. This will improve the soil's hydraulic conductivity and consequently help with the leaching of soluble salts (Oster 1982; Mahmoodabadi et al. 2012). Fresh water treatment $\mathrm{B}$ also showed a sharp decline in salinity when compared to the saline water treatment $C$. These results were in agreement with S. K. Gupta and I. C. Gupta [28]. The utilization of drainage water for leaching saline sodic soil can contribute effectively in sustainable water management of scarce fresh water resources in the Jordan Valley.

The relationships between the decline in electrical conductivity (EC) and the amount of drainage water $\left(\mathrm{m}^{3}\right)$ from the gypsum-amended soil (A), fresh water (B), and saline water $(C)$ treatments over the experimental period are shown in Figures 3(a), 3(b), and 3(c). The EC of drainage water dramatically decreased in the first few weeks, and then a gradual decrease was observed until a steady state was reached at the end of the experiment. The gypsum-amended soil, treatment $\mathrm{A}$, showed the fastest salt leaching process compared with both the fresh, B, and saline, $\mathrm{C}$, water treatments. This may be the result of increased displacement of $\mathrm{Na}^{+}$due to an increased soil-solution of $\mathrm{Ca}^{+2}$ from amendments and subsequent leaching of the replaced $\mathrm{Na}^{+}$through 


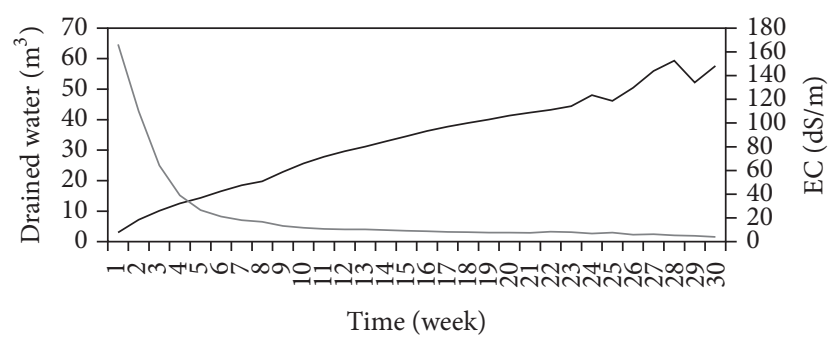

(a) Gypsum experiment: leaching water versus EC

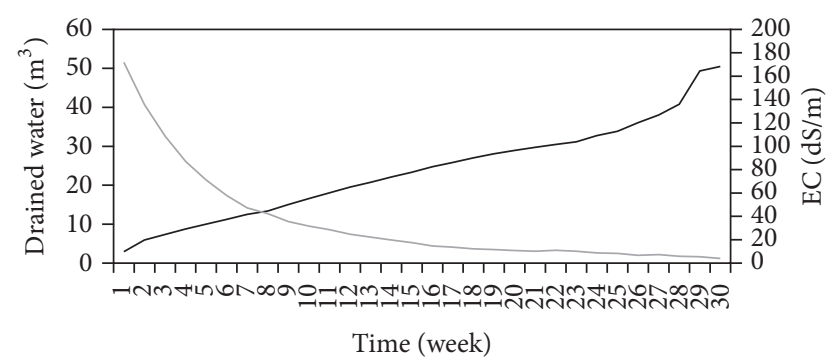

(b) Fresh water experiment: leaching water versus EC

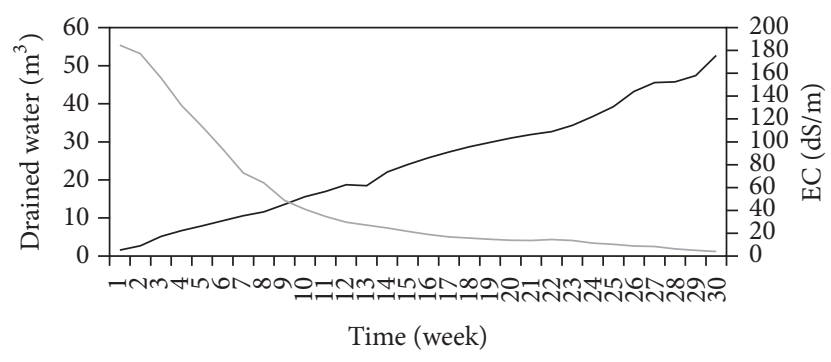

(c) Saline water experiment: leaching water versus EC

FIGURE 3: Electrical conductivity and quantities of drained water recorded during the experiment ((a) gypsum, (b) fresh water, and (c) saline water). The black line represents the leaching water quantity $\left(\mathrm{m}^{3}\right)$, and the gray line is the EC.

drained water [29] (Mahmoodabadi et al. 2012). The results also showed that gypsum treatments required smaller quantities of water to remove $\mathrm{Na}^{+}$from soil compared with fresh and saline water treatments. Similar trends were reported for saline and saline-alkaline soils [11, 29, 32, 33]. The leaching process at the beginning of the experiment showed the removal of salts from the easily percolated water in the macropores. However, in later stages of the leaching process, the drop of EC slowed as the leaching water diffused through micropores by capillary action. It is known that salinity affected soil undergoes variable equilibrium conditions through the leaching processes until complete equilibrium between soil solution and soil particles is achieved. At the end of the leaching experiment, the equilibrium process proceeded very slowly, consuming a large amount of water and time. It was found that a complete equilibrium need not be reached because partial equilibrium is sufficient to save water and time [34].

3.3. Changes in Drainage Water's Chemical Composition. There was a sharp decline in cations $\left(\mathrm{Na}^{+}, \mathrm{Ca}^{+2}\right.$, and $\left.\mathrm{Mg}^{+2}\right)$ and $\mathrm{Cl}^{-}$concentrations for drainage water during the early stages of the leaching experiments, Figure 4. This decrease coincided with a decrease in SAR and a sharp drop in ESP which was continuously represented in the soil leaching process (Figure 5). Furthermore, a similar trend was observed for $\mathrm{Cl}^{-}$ion. The leaching process of ions from the soil was dependent upon ion radius, mobility, and adsorption affinity on soil paste. The observed reduction in SAR and ESP may have been caused by $\mathrm{Na}^{+}$reduction in the soil solution over time. The replacement of $\mathrm{Na}^{+}$and $\mathrm{K}^{+}$by $\mathrm{Ca}^{+2}$ in the exchangeable sites probably led to an initial increase in soluble $\mathrm{Na}^{+}$and $\mathrm{K}^{+}$which then decreased over time.

\subsection{Physical and Chemical Soil Properties after the Leaching} Experiment. The chemical properties of the collected soil samples showed a decline in EC after the leaching experiment (see Table 2). PH values of the soil ranged between 7.64 and 7.94 for the three treatments at all depths. No sodicity development was observed in the leached soil during or after the leaching experiment. There was a sharp drop in EC values along the soil profile during the soil leaching for all treatment methods (A, B, and C). The EC values dropped from 111, 51, and $44 \mathrm{dS} \mathrm{m}^{-1}$ for the three soil depths (0$50,50-100$, and $100-150 \mathrm{~cm}$ ) to $0.94-1.18,1.36-1.82$, and 2.01-3.2 $\mathrm{dS} \mathrm{m}^{-1}$, respectively. Some lower EC values near the soil's surface for all treatments were noticed because of the excess leaching resulting from irrigation. Since salts are very mobile, soil EC values are being affected not only by soil amendment but also by the movement of water in the soil (Zhang et al. 2007). Moreover, since downward leaching of salt intensifies with irrigation or leaching, some of the salt should have been moved downward. Significant variations in cation distribution were found as a sharp decrease in exchangeable $\mathrm{Na}^{+}$and $\mathrm{K}^{+}$ions for all treatments at all depths. The results showed that the exchangeable $\mathrm{Na}^{+}$concentration dropped from $7.5,4.1$, and $3.8 \mathrm{meq} / 100 \mathrm{~g}$ to $1.59,0.98$, and $0.87 \mathrm{meq} / 100 \mathrm{~g}$ at $0-50 \mathrm{~cm}$ depth and to $2.02,1.79$, and 1.48 at $50-100 \mathrm{~cm}$ depth and $2.64,2.38$, and 1.65 at $100-150 \mathrm{~cm}$ depth for treatments A, B, and C, respectively, as displayed in Tables 1 and 2 .

Further, application of gypsum provided a readily available source of $\mathrm{Ca}^{+2}$ ions in the soil solution. It replaced the exchangeable $\mathrm{Na}^{+}$ions which then came into the soil solution and subsequently increased the electrolyte concentration. This increase in electrolyte concentration in turn increased the soluble salt concentration of the percolating solution [35]. Therefore, $\mathrm{Ca}^{+2}$ and $\mathrm{Mg}^{+2}$ concentrations increased from 6.7, 6.3 , and $5.7 \mathrm{meq} / 100 \mathrm{~g}$ to $14.2,14.9$, and $15.0 \mathrm{meq} / 100 \mathrm{~g}$, to 13.4 , 13.5 , and 13.6 , and to $12.3,12.6$, and 13.4 at $0-50,50-100$, and $100-150 \mathrm{~cm}$ depths for treatments A, B, and C, respectively. These results support the idea that $\mathrm{Ca}^{+2}$ ion substitutes $\mathrm{Na}^{+}$ ion in the soil, which leads to leaching the $\mathrm{Na}^{+}$ion from the soil. Additionally, this can be related to the higher mobility of $\mathrm{Na}^{+}$and $\mathrm{K}^{+}$than $\mathrm{Ca}^{+2}$ and $\mathrm{Mg}^{+2}$ in the soil profile during the leaching process (Mahmoodabadi et al. 2012).

3.5. Statistical Analysis Significance. The results of the statistical analysis were designated using three superscript letters a, 

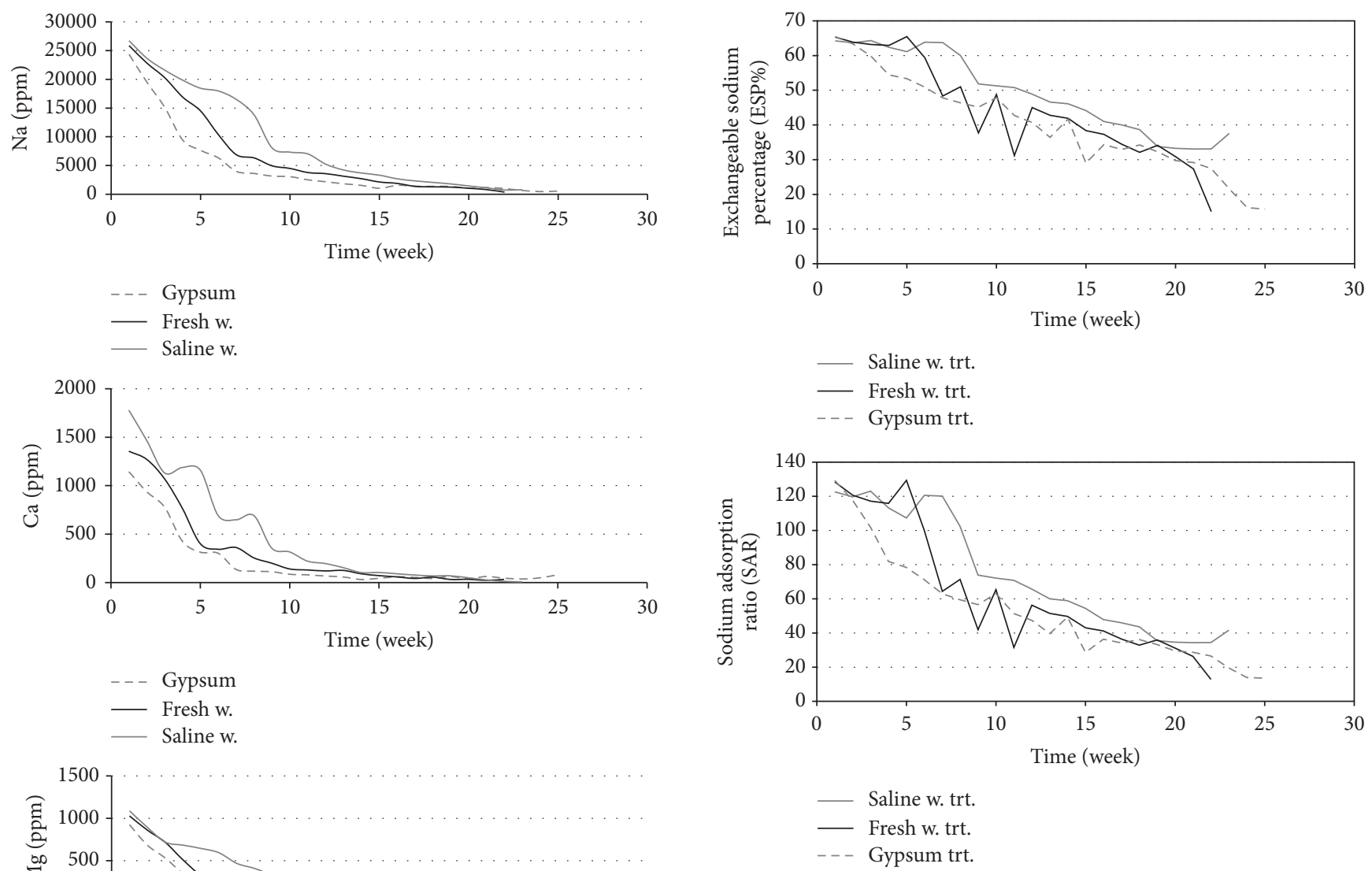

FIGURE 5: SAR and ESP in drainage water during the leaching experiment for gypsum, fresh water, and saline water treatments.

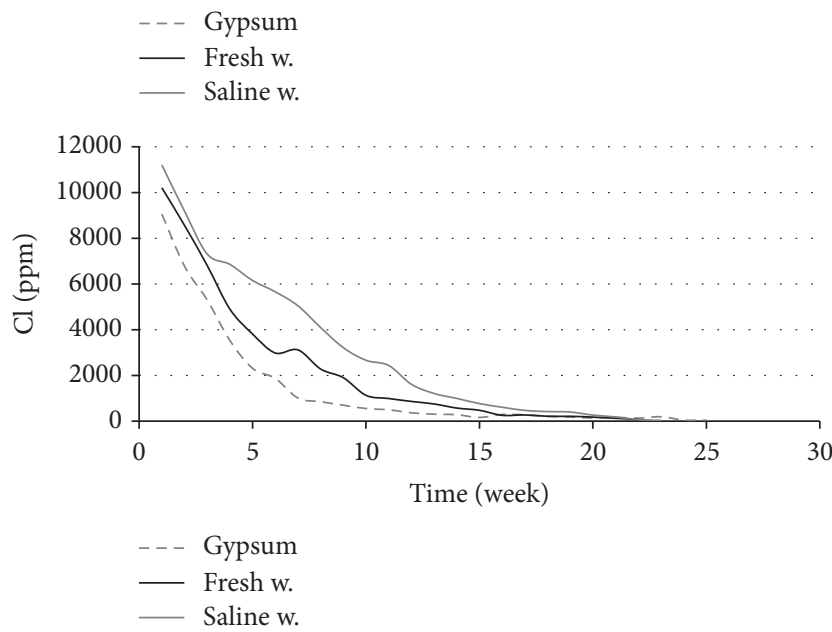

FIgURE 4: Decline in ionic composition $\left(\mathrm{Na}^{+}, \mathrm{Ca}^{+2}, \mathrm{Mg}^{+2}\right.$, and $\left.\mathrm{Cl}^{-}\right)$ of drainage water for all treatments.

b, or c, where the significance was tested at a $95 \%$ confidence limit (Table 2). The treatments followed by the same letter were not significantly different at $P<0.05$. Significant differences were observed only at a soil depth $100-150 \mathrm{~cm}$ among the different treatments.

\section{Conclusion}

It can be concluded that utilization of agricultural drainage water in preliminary stages of soil leaching for saline-sodic soil can save more than $60 \%$ of fresh water requirements for soil reclamation. Likewise, adding gypsum to saline-sodic soil reduced the amount of water needed for leaching. The drop in EC with gypsum-amended soil was relatively faster than the other treatments because of flocculation of soil particles, which is a distinctive phenomenon with use of gypsum. A sharp decrease in exchangeable $\mathrm{Na}^{+}$and $\mathrm{K}^{+}$ions for all treatments and at all depths was also noticed with an increase in exchangeable $\mathrm{Ca}^{+2}$ and $\mathrm{Mg}^{+2}$. Overall, the three investigated leaching treatment scenarios were able to reduce soil salinity to less than $4 \mathrm{dS} \mathrm{m}^{-1}$ which conformed to the study's purpose.

However, the utilization of saline water resources, such as brackish and irrigation drainage water along with a gypsum application for leaching saline-sodic soils, can be an invaluable practice in the Jordan Valley, especially as fresh water becomes an increasingly valuable resource. Moreover, as gypsum is a relatively inexpensive material to purchase in large quantities, the research pointed out that using both saline water and gypsum might be a potential reclamation material for saline-sodic soils on a large scale in arid and semiarid environments. It is also recommended to investigate 
other soil reclaiming materials, such as phosphoric acid $\left(\mathrm{H}_{3} \mathrm{PO}_{4}\right)$ with saline-sodic soils alongside saline water.

\section{Competing Interests}

The author declares that he has no competing interests.

\section{Acknowledgments}

This work was supported financially by the Higher Council for Science and Technology (HCST), Amman, Jordan. The researcher would like to extend his thanks to those who helped, encouraged, or participated directly or indirectly in this study. Additionally, the author would like to express deep gratitude to Mrs. Jennifer Benaggoun and Dr. Christopher Quinn for their editing skills.

\section{References}

[1] L. A. Richards, Ed., Diagnosis and Improvements of Saline and Alkali Soils, Handbook No 60 (USDA), United States Department of Agriculture (USDA), Washington, DC, USA, 1954.

[2] N. Al-Abed, J. Amayreh, A. Al-Afifi, and G. Al-Hiyari, "Bioremediation of a Jordanian saline soil: a laboratory study," Communications in Soil Science and Plant Analysis, vol. 35, no. 9-10, pp. 1457-1467, 2004.

[3] A. Nerd and D. Pasternak, "Growth, ion accumulation, and nitrogen fractioning in Atriplex barclayana grown at various salinities," Journal of Range Management, vol. 45, no. 2, pp. 164166, 1992.

[4] F. I. Massoud, "Basic principles for prognosis and monitoring of salinity and sodicity," in Proceedings of the International Conference on Managing Saline Water for Irrigation, pp. 432454, Texas Tech University, Lubbock, Tex, USA, August 1976.

[5] A. Jiries and K.-P. Seiler, "Water movement in typical soils in the Jordan Valley," Jordan Metrological Journal and Agriculture, vol. 22, no. 3, pp. 5-12, 1995.

[6] A. Khlaifat, M. Hogan, G. Phillips, K. Nawayseh, J. Amira, and E. Talafeha, "Long-term monitoring of the Dead Sea level and brine physico-chemical parameters "from 1987 to 2008", Journal of Marine Systems, vol. 81, no. 3, pp. 207-212, 2010.

[7] F. Nasir, M. Batarseh, A. H. Abdel-Ghani, and A. Jiries, "Free amino acids content in some halophytes under salinity stress in arid environment, Jordan," Clean-Soil, Air, Water, vol. 38, no. 7, pp. 592-600, 2010.

[8] E. Amezketa, R. Aragüés, and R. Gazol, "Efficiency of sulfuric acid, mined gypsum, and two gypsum by-products in soil crusting prevention and sodic soil reclamation," Agronomy Journal, vol. 97, no. 3, pp. 983-989, 2005.

[9] O. E. Mohawesh, "Evaluation of evapotranspiration models for estimating daily reference evapotranspiration in arid and semiarid environments," Plant, Soil and Environment, vol. 57, no. 4, pp. 145-152, 2011.

[10] O. E. Mohawesh and S. A. Talozi, "Comparison of Hargreaves and FAO56 equations for estimating monthly evapotranspiration for semi-arid and arid environments," Archives of Agronomy and Soil Science, vol. 58, no. 3, pp. 321-334, 2012.

[11] M. Gharaibeh, N. Eltaif, and S. Shra'a, "Leaching curves of highly saline-sodic soil amended with phosphoric acid and phosphogypsum," in Proceedings of the 2nd International Conference on Agricultural and Animal Science, International Proceedings of Chemical, Biological and Environmental Engineering (IPCBEE), vol. 22, IACSIT Press, Singapore, 2011.

[12] O. Mohawesh, "Assessment of pedotransfer functions (PTFs) in predicting soil hydraulic properties under arid and semi-arid environments," Journal of Agricultural Sciences, vol. 9, no. 4, pp. 475-492, 2013.

[13] MOA, "Ministry of Agriculture," Internal Report 2009, Ministry of Agriculture, Amman, Jordan, 2009.

[14] MWI, "Ministry of Water and Irrigation," Annual Report 1998, Laboratory Department at the Water Authority of Jordan, DierAla Laboratories, Amman, Jordan, 1998.

[15] US Salinity Laboratory Staff, "Diagnosis and improvement of saline and alkali soils," in USDA Agricultural Handbook No. 60, US Government Printing Office, Washington, DC, USA, 1954.

[16] J. D. Rhoades, "Soluble salts," in Methods of Soil Analysis, Part 2: Chemical and Microbiological Properties, A. L. Page, R. H. Muler, and D. R. Keeney, Eds., no. 9, part 2, pp. 167-179, Soil Science Society of America, Madison, Wis, USA, 2nd edition, 1982.

[17] D. L. Rowell, Soil Science: Methods and Applications, Springer, Berlin, Germany, 1994.

[18] G. W. Gee and J. W. Bauder, "Particle-size analysis," in Methods of Soil Analysis, A. Klute, Ed., no. 9, part 1, pp. 383-411, Soil Science Society of America (SSSA), Madison, Wis, USA, 1986.

[19] D. Sparks, A. Page, P. Helmke, R. Loeppert, D. W. Nelson, and L. E. Sommers, "Total carbon, organic carbon, and organic matter," in Methods of Soil Analysis Part 3-Chemical Methods, SSSA Book Series, Soil Science Society of America, American Society of Agronomy, Madison, Wis, USA, 1996.

[20] E. Schlichting, H. P. Blume, and K. Stahr, Boden Kundliches Prktikum, Blackwell Wissenschaft, Wien, Austria, 1995.

[21] R. G. D. Steel and J. H. Torrie, Principles and Procedures of Statistics, McGraw-Hill, New York, NY, USA, 2nd edition, 1980.

[22] E. Bresler, B. L. McNeal, and D. L. Carter, Saline and Sodaic Soil: Principles-Dynamic-Modeling, Springer, Berlin, Germany, 1982.

[23] M. Qadir, A. Ghafoor, and G. Murtaza, "Amelioration strategies for saline soils: a review," Land Degradation and Development, vol. 11, no. 6, pp. 501-521, 2000.

[24] J. Bolton, "Changes in soil pH and exchangeable calcium in two liming experiments on contrasting soils over 12 years," The Journal of Agricultural Science, vol. 89, no. 1, pp. 81-86, 1977.

[25] A. Hardan, "Removal of salts from undisturbed saline-alkali soil columns by different leaching waters," in Proceedings of the Man, Food, and Agriculture in the Middle East Symposium, pp. 409431, American University of Beirut, 1969.

[26] M. I. Batarseh, A. Rawajfeh, K. K. Ioannis, and K. H. Prodromos, "Treated municipal wastewater irrigation impact on olive trees (Olea Europaea L.) at Al-Tafilah, Jordan," Water, Air, and Soil Pollution, vol. 217, no. 1-4, pp. 185-196, 2011.

[27] A. Al Zubaidi and K. M. Hassan, "Leaching of some salt affected soils in Iraq using drainage water," Iraqi Journal of Agriculture Sciences, vol. 13, pp. 219-234, 1978.

[28] S. K. Gupta and I. C. Gupta, "Land development and leaching," in Management of Saline Soils and Waters, pp. 136-152, Mohan Primlani, New Dehli, India, 1987.

[29] M. A. Gharaibeh, N. I. Eltaif, and O. F. Shunnar, "Leaching and reclamation of calcareous Saline-sodic soil by moderately Saline and moderate-SAR water using Gypsum and Calcium Chloride," Journal of Plant Nutrition and Soil Science, vol. 172, no. 5, pp. 713-719, 2009. 
[30] M. E. Sumner, "Sodic soils: new perspectives," Australian Journal of Soil Research, vol. 31, no. 6, pp. 683-750, 1993.

[31] I. Shainberg and J. Letey, "Response of soils to sodic and saline conditions," Hilgardia, vol. 52, no. 2, pp. 1-57, 1984.

[32] G. A. Al-nakshabandi, A. Alzubaidi, H. N. Ismail, F. Al-rayhani, and E. Al-hadithy, "Leaching of euphrates saline soil in lysimeters," Journal of Soil Science, vol. 22, no. 4, pp. 508-513, 1971.

[33] I. M. Habib, "Leaching of saline soils in monoliths of Iraq," Egyptian Journal of Soil Science, vol. 14, pp. 149-158, 1974.

[34] S. Muhammed, B. L. McNeal, C. A. Bower, and P. F. Pratt, "Modification of the high-salt water method for reclaiming sodic soils," Soil Science, vol. 108, no. 4, pp. 249-256, 1969.

[35] M. Qadir, D. Steffens, F. Yan, and S. Schubert, "Sodium removal from a calcareous saline-sodic soil through leaching and plant uptake during phytoremediation," Land Degradation and Development, vol. 14, no. 3, pp. 301-307, 2003. 

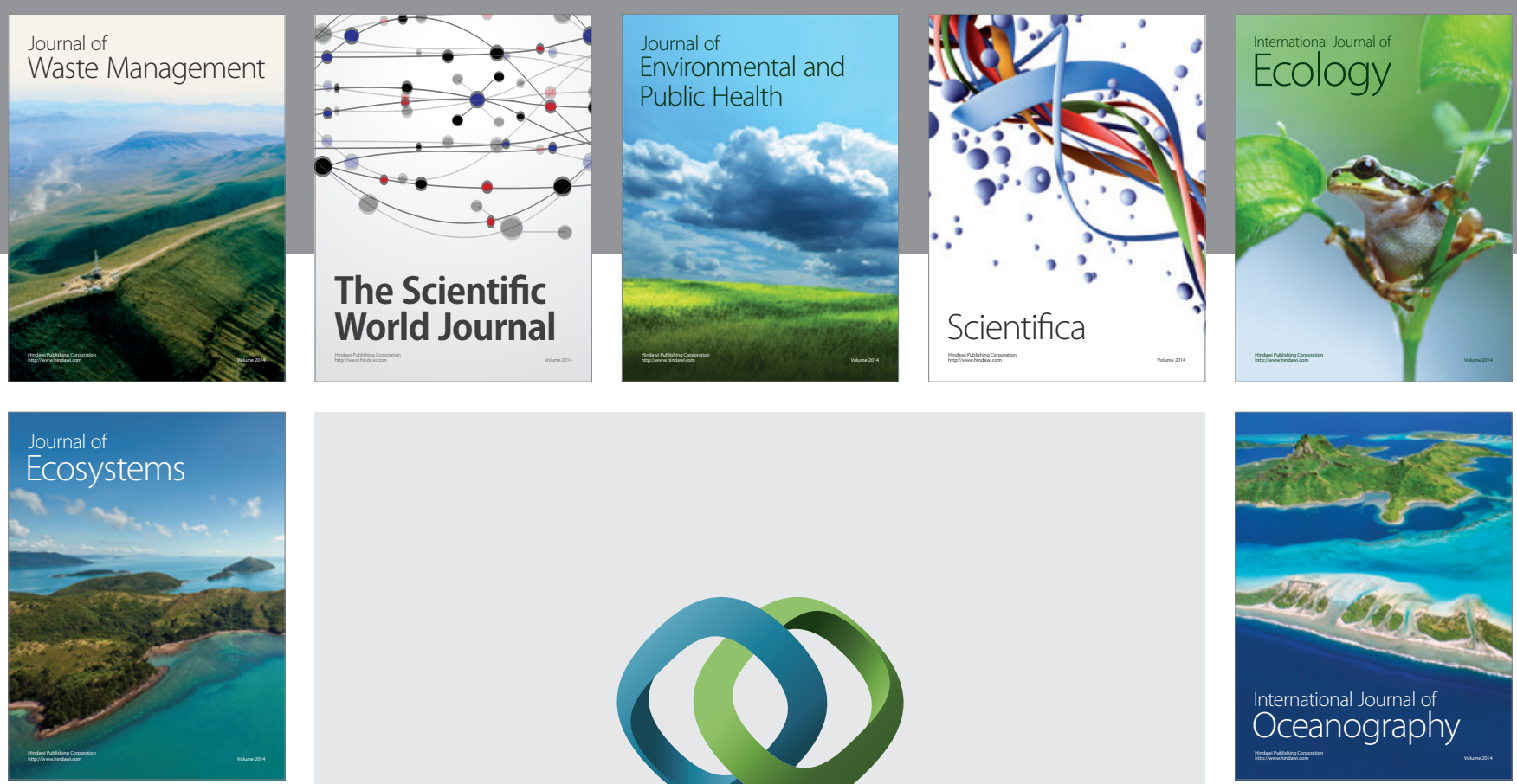

The Scientific World Journal
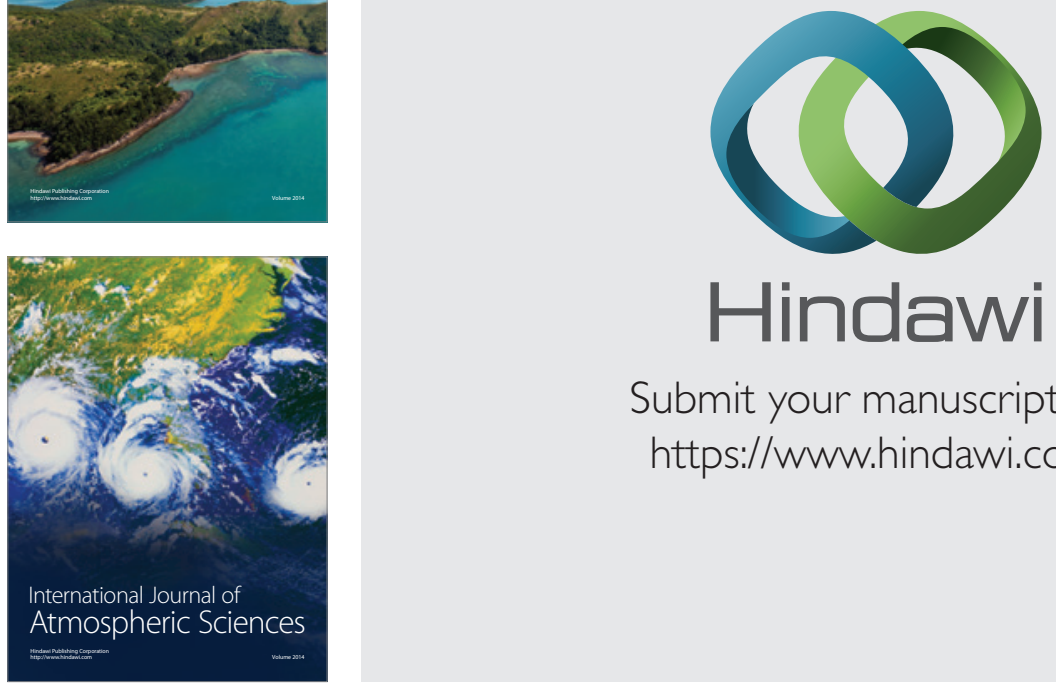

Submit your manuscripts at

https://www.hindawi.com
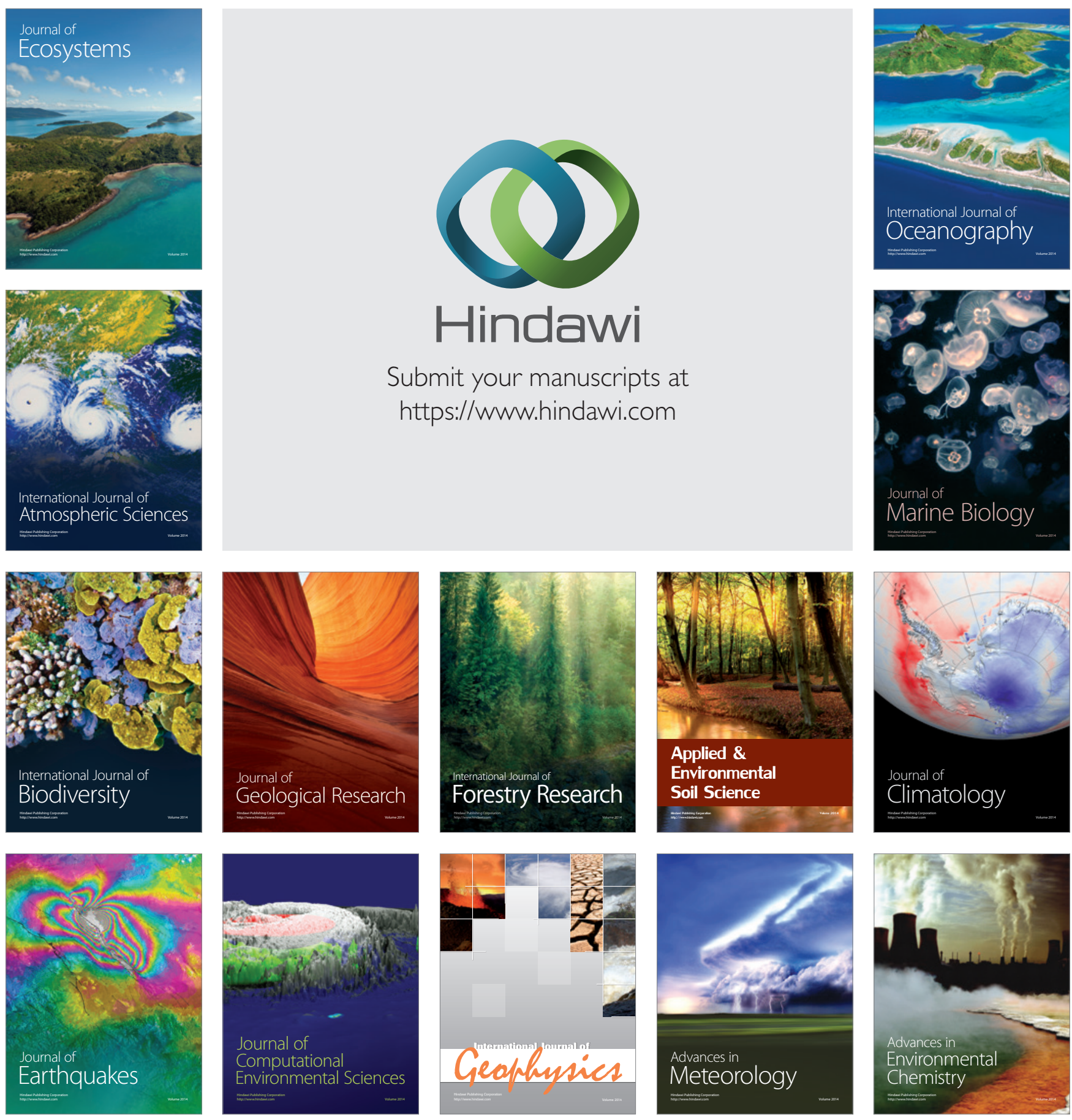